\title{
Effects of Various Preoperative Factors on Surgical Results in Patients Aged 35 and below who Undergone Coronary Artery Bypass Surgery
}

\author{
Mehmet Kızılay, (1) Zeynep Aslan, 는al Vural, (i) Ahmet Arif Ağlar, (1) Ahmet Yavuz Balcı
}

Department of Cardiovascular Surgery, University of Health Sciences Siyami Ersek Training and Research Hospital, Istanbul, Turkey

\begin{abstract}
Introduction: In this study, the effects of various known cardiac risk factors on morbidity and surgical results in a population of patients aged 35 and below were studied.

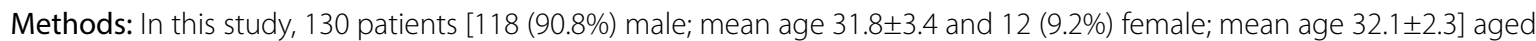
35 and below (17-35 years of age) who underwent CABG in our center between the years of 2005 and 2016 were assessed retrospectively. Patients grouped by gender were assessed concerning cardiovascular risk factors, demographic features, some preoperative and postoperative parameters.

Results: Concerning female patients, 33.3\% had diabetes mellitus, whereas $25 \%$ had hypertension and a family history of coronary artery disease. As for the male patients, 50.8\% had diabetes mellitus, 31.4\% had hypertension, and $21.2 \%$ had a family history of coronary artery disease. The ratio of smokers in the male and female patient groups was $68.6 \%$ and $33.3 \%$, respectively. CRP values were found to be higher in $47.7 \%$ of the patients. $33.8 \%$ of all patients (44 out of 130) had a previous myocardial infarction. Preoperatively measured mean EF value was 53\%. While $94.6 \%$ of all patients (123 out of 130) were operated on an elective basis, 5.4\% (7 out of 130) underwent an emergent operation. 9.2\% of all patients (12 out of 130) underwent off-pump coronary artery bypass surgery, whereas, in the rest, cardiopulmonary bypass was employed. Mean number of grafts used was 2.4 \pm 1.2 .

Discussion and Conclusion: The findings suggest that the presence of such cardiac risk factors as hypertension, diabetes mellitus, and smoking history increase coronary artery disease risk and postoperative morbidity significantly and adversely affect life expectancy in the young patient population, irrespective of gender. Thus, it could be easily postulated that smoking is the most important preventable risk factor for early-onset of coronary artery disease.

Keywords: Coronary artery by-pass surgery; gender; young age.
\end{abstract}

C ardiovascular diseases play an increasingly global role as the major cause of mortality and morbidity. Coronary Artery Disease (CAD) is the leading cause of death in developed countries ${ }^{[1]}$. The incidence of CAD in young adults has been increasing even though it is primarily the disease of the middle and advanced aged population ${ }^{[2-4]}$. The young population differs concerning risk factors, mortality, morbidity, and short and long-term results from the elderly population. The young patients have multiple risk factors for coronary artery disease. Smoking, diabetes mel-

Correspondence (İletişim): Kızılay, M.D. Saglik Bilimleri Universitesi Siyami Ersek Egitim ve Arastirma Hastanesi,

Kalp ve Damar Cerrahisi Anabilim Dali, Istanbul, Turkey

Phone (Telefon): +90 5334218433 E-mail (E-posta): kzlay@yahoo.com

Submitted Date (Başvuru Tarihi): 15.10.2018 Accepted Date (Kabul Tarihi): 11.02.2019

Copyright 2020 Haydarpaşa Numune Medical Journal

OPEN ACCESS This is an open access article under the CC BY-NC license (http://creativecommons.org/licenses/by-nc/4.0/) 
litus (DM), hypertension ( $\mathrm{HT})$, family history, hypercholesterolemia, obesity and other factors (e.g., oral contraceptive use in young women, cocaine use) at the young age group is known to play a role in the etiology of coronary atherosclerosis. In parallel with the increase in coronary artery disease, the frequency of coronary artery bypass surgery is increasing at the young age group patients, especially in patients with left main coronary and diabetes mellitus. Coronary artery bypass operation increases life expectancy and increases the quality of life in patients with three vessels and more lesions ${ }^{[5]}$. This study aims to address the etiological factors playing a role in CAD, as well as to assess the morbidity and mortality rates of CABG in the young patient population (aged from 17 to 35 ).

\section{Materials and Methods}

Between the years of 2005 and 2016, 20700 patients, of which 4359 are female and 16341 are male, had undergone CABG surgery in our center. After the approval of the ethics committee, 130 patients aged between 17 to 35 , who underwent $C A B G$, were studied retrospectively in this study. The mean age of the patients was 31.8 \pm 3.3 (17-35) and 118 out of 130 patients $(90.8 \%)$ were male, while 12 patients (9.2\%) were female.

Patients were studied concerning urgency of operation (elective vs. emergent operation) in addition to the risk factors and laboratory parameters they presented (e.g., age, gender, family history, hypertension, diabetes mellitus, smoking, previous myocardial infarction, CRP, thyroid hormone and cholesterol levels, echocardiographical findings, including preoperative and postoperative EF values). The presence of critical LMCA stenosis, ITA or other arterial graft utilization, number of grafts utilized, need for inotropic agents, IABP implantation and reoperation, length of ICU and length of hospital stay, and early and late mortality rates were the other parameters included in the assessment.

Surgical Intervention: Access to the thoracic cavity was achieved using median sternotomy in all patients. In 12 patients (9.2\%), off-pump coronary artery bypass (OPCAB) with beating heart technique was employed, while in the rest of the patients $(90.8 \%)$, the operation was conducted under the standard cardiopulmonary bypass (CPB) technique using membrane oxygenator. Aortic and cavoatrial cannulation was preferred for the institution of CPB. Cardioprotection was afforded by applying topical and mild systemic hypothermia $\left(30-32^{\circ} \mathrm{C}\right)$, and by antegrade cold blood cardioplegia for both induction and maintenance, by perfusing aortic root with intervals of 20 minutes and each free graft on completion of the respective distal anastomosis, of the diastolic arrest. Distal anastomoses were completed under the aortic cross-clamp, whereas proximal anastomoses were carried out under the partially occluding aortic clamp. In 123 patients, left internal thoracic artery (LITA) graft was utilized for anastomosis with the left anterior descending artery (LAD) whereas in the rest, with the exception of four patients in whom the right internal thoracic artery (RITA) was anastomosed to the right coronary artery (RCA), saphenous vein grafts were employed for the revascularization of myocardium. Mean number of anastomoses performed per patient was $2.8 \pm 0.8$ Mean aortic cross-clamp time was $39.9 \pm 15.3$ minutes.

\section{Statistical Analysis}

The continuous variables were expressed as mean \pm standard deviation, while categorical variables were considered as numbers or percentages. For comparison of two groups of continuous variables concerning normal distribution, Shapiro-Wilk Test was used. Non-normally distributed variables were compared using the Mann-Whitney U Test. Categorical or nominal variables were analyzed by both Yate's Correction Test and Fisher's Exact Test. The effects of demographical variables on post-operative complications were also analyzed by utilizing both Yate's Correction Test and Fisher's Exact Test. The strength of the relationship between two sets of data was analyzed by Spearman's Rank-Order Correlation. Correlated data were analyzed by logistic regression analysis. $\mathrm{P} \leq 0.05$ values were regarded as significant. Kaplan-Meier log-rank test was employed for the survival analysis. All analyses were carried out using IBM SPSS Statistics for Windows, Version 20.0 (IBM Corporation, Armonk, New York, USA).

\section{Results}

Descriptive statistics related to the variables were shown in Table 1. Except for smoking, all other demographical features were similar for both gender. In $47.7 \%$ of the patients $(n=62)$, CRP levels were found to be higher than normal (Table 2). Mean CRP levels were $5.8 \pm 1.9 \mathrm{mg} / \mathrm{dl}$ and $0.5 \pm 1.1$ $\mathrm{mg} / \mathrm{dl}$ in patients with elevated and normal CRP levels, respectively. It was found that the patients with higher CRP levels also had significantly higher preoperative $E F(p=0.01)$, postoperative EF $(p=0.04), \mathrm{HDL}(p=0.04), \mathrm{fT}_{3}(p=0.01), \mathrm{TSH}$ $(p=0.02)$ values than those patients with normal CRP lev- 
Table 1. Descriptive statistics of the variables examined by gender

\begin{tabular}{|c|c|c|c|c|c|}
\hline \multirow[t]{2}{*}{ Variables } & \multicolumn{2}{|c|}{$\begin{array}{c}\text { Female } \\
(n=12)\end{array}$} & \multicolumn{2}{|c|}{$\begin{array}{c}\text { Male } \\
(n=118)\end{array}$} & \multirow[t]{2}{*}{$\mathbf{p}$} \\
\hline & Mean & SD & Mean & SD & \\
\hline Preoperative EF (\%) & 54 & 9 & 53 & 10 & $0.92^{\mathrm{a}}$ \\
\hline Age (year) & 32 & 2 & 32 & 3 & $0.85^{a}$ \\
\hline CRP $(\mathrm{mg} / \mathrm{dL})$ & 1.81 & 2.29 & 4.56 & 11.83 & $0.45^{a}$ \\
\hline Total Cholesterol (mg/dL) & 182.5 & 25.32 & 196.48 & 69.61 & $0.62^{\mathrm{a}}$ \\
\hline Triglycerid (mg/dL) & 214.5 & 172.79 & 173.51 & 88.42 & $0.93^{a}$ \\
\hline $\mathrm{HDL}(\mathrm{mg} / \mathrm{dL})$ & 37.5 & 9.58 & 35.92 & 9.58 & $0.60^{a}$ \\
\hline LDL (mg/dL) & 109 & 19.24 & 125.61 & 60.81 & $0.63^{a}$ \\
\hline VLDL (mg/dL) & 36.05 & 16.33 & 34.91 & 15.51 & $0.96^{a}$ \\
\hline $\mathrm{rT}_{3}(\mathrm{pgr} / \mathrm{dL})$ & 2.56 & 1.22 & 2.32 & 1.41 & $0.62^{a}$ \\
\hline $\mathrm{rT}_{4}(\mathrm{ng} / \mathrm{dL})$ & 0.89 & 0.38 & 1.57 & 7.42 & $0.71^{a}$ \\
\hline \multirow[t]{2}{*}{ TSH (ulU/dL) } & 1.33 & 0.83 & 3.03 & 15.89 & $0.85^{a}$ \\
\hline & $\mathbf{n}$ & $\%$ & $\mathbf{n}$ & $\%$ & $\mathbf{p}$ \\
\hline Diabetes Mellitus & 4 & 33.3 & 52 & 50.8 & $0.68^{b}$ \\
\hline Hypertension & 3 & 25 & 37 & 31.4 & $0.75^{b}$ \\
\hline Cigarette usage & 4 & 33.3 & 81 & 68.6 & $0.02^{b}$ \\
\hline Post MI & 2 & 16.7 & 42 & 35.6 & $0.34^{b}$ \\
\hline Alcohol & 0 & 0 & 7 & 5.9 & $1.00^{b}$ \\
\hline Emergency & 1 & 8.3 & 6 & 5.1 & $0.50^{b}$ \\
\hline Elective & 11 & 91.7 & 112 & 94.9 & \\
\hline Family History & 3 & 25 & 25 & 2.2 & $0.72^{b}$ \\
\hline IABP & 0 & 0 & 6 & 5.1 & $1.00^{b}$ \\
\hline Main Coronary & 2 & 16.7 & 8 & 6.8 & $0.23^{b}$ \\
\hline
\end{tabular}

$\mathrm{a}=$ Mann-Whitney $\mathrm{U}$ test, $\mathrm{b}=$ Yate's Correction Test or Fischer's Exact Test. $\mathrm{p}<0.05$ is accepted as significant. (MI: Myocardial infarction, IABP $=$ IntraAortic Balloon Pump, EF= Ejection fraction, $\mathrm{CRP}=\mathrm{C}$-Reactive Protein).

els. CRP levels were significantly higher $(p=0.01)$ in patients with diabetes mellitus.

Among the patients with and without diabetes mellitus, no significant difference was detected concerning postoperative complications and length of hospital stay ( $p>0.05$; Table 3). The patients with diabetes mellitus had a significantly higher number of coronary bypasses $(p=0.01)$. Emergently operated patients were found to have lower EF values $(p=0.02)$, and higher mortality rates $(p=0.01)$ when compared to the patients operated electively. Postoperative data related to patients were presented in (Table 4). In 12 patients (9.2\%), off-pump coronary artery bypass (OPCAB) with beating heart technique was employed, while in the rest of the patients (90.7\%), the operation was conducted under the standard cardiopulmonary bypass $(\mathrm{CPB})$ using membrane oxygenator. In the patients operated under $\mathrm{CPB}$, the mean aortic cross-clamp time was $39.9 \pm 15.3$ minutes. The mean number of coronary bypasses carried out per patient was $2.7 \pm 0.82$. The mean time to extubation was $8.2 \pm 5.2$ hours. The mean length of ICU
Table 2. Distribution of laboratory findings and postoperative findings according to CRP elevation

\begin{tabular}{|c|c|c|c|c|c|}
\hline & \multicolumn{4}{|c|}{$\begin{array}{c}\text { CRP } \\
(n=112)\end{array}$} & \multirow[t]{3}{*}{$\mathbf{p}$} \\
\hline & \multicolumn{2}{|c|}{ Negative } & \multicolumn{2}{|c|}{ Positive } & \\
\hline & Mean & SD & Mean & SD & \\
\hline Lenght of Hospital Stay & 7 & 2 & 7 & 3 & $0.58^{a}$ \\
\hline Lenght of ICU Stay & 1 & 0 & 1 & 1 & $0.98^{a}$ \\
\hline Preoperative EF & 51 & 11 & 55 & 10 & $0.01^{a}$ \\
\hline Postoperative EF & 50 & 12 & 53 & 13 & $0.04^{a}$ \\
\hline Number of Coronary & 3 & 1 & 2 & 1 & $0.52^{a}$ \\
\hline \multicolumn{6}{|l|}{ Bypasses } \\
\hline Total cholesterol & 179.62 & 57.84 & 203.61 & 77.31 & $0.16^{a}$ \\
\hline Triygliceride & 182.79 & 113.72 & 170.94 & 82.93 & $0.85^{\mathrm{a}}$ \\
\hline $\mathrm{HDL}$ & 34.83 & 9.46 & 37.80 & 9.97 & $0.04^{a}$ \\
\hline LDL & 107.25 & 48.17 & 131.30 & 68.24 & $0.18^{a}$ \\
\hline VLDL & 34.25 & 16.99 & 35.02 & 16.11 & $0.61^{a}$ \\
\hline $\mathrm{fT}_{3}$ & 1.92 & 1.51 & 3.07 & 0.63 & $0.01^{a}$ \\
\hline $\mathrm{fT}_{4}$ & 3.44 & 13.91 & 1.02 & 0.28 & $0.51^{a}$ \\
\hline \multirow[t]{2}{*}{ TSH } & 1.24 & 1.19 & 4.49 & 20.51 & $0.02^{\mathrm{a}}$ \\
\hline & $\mathbf{n}$ & $\%$ & $\mathbf{n}$ & $\%$ & $\mathbf{p}$ \\
\hline \multicolumn{6}{|l|}{ Gender } \\
\hline Female & 3 & 33.3 & 6 & 66.7 & $0.60^{b}$ \\
\hline Male & 31 & 35.6 & 56 & 64.4 & \\
\hline \multicolumn{6}{|l|}{ Mortality } \\
\hline No & 33 & 35.9 & 59 & 64.1 & ns \\
\hline Yes & 1 & 25 & 3 & 75.0 & \\
\hline Revison Surgery for & 31 & 33.7 & 61 & 66.3 & ns \\
\hline \multicolumn{6}{|l|}{ Bleeding } \\
\hline \multicolumn{6}{|l|}{ No } \\
\hline Yes & 3 & 75 & 1 & 25.0 & \\
\hline \multicolumn{6}{|l|}{ The need for dialysis } \\
\hline No & 33 & 35.5 & 60 & 64.5 & ns \\
\hline Yes & 1 & 33.3 & 2 & 66.7 & \\
\hline \multicolumn{6}{|l|}{ LIMA } \\
\hline No & 3 & 50 & 3 & 50 & $0.36^{b}$ \\
\hline Yes & 31 & 34.4 & 59 & 65.6 & \\
\hline \multicolumn{6}{|l|}{ RIMA } \\
\hline No & 33 & 35.1 & 61 & 64.9 & ns \\
\hline Yes & 1 & 50 & 1 & 50 & \\
\hline \multicolumn{6}{|l|}{ ECMO } \\
\hline No & 33 & 34.7 & 62 & 65.3 & ns \\
\hline Yes & 1 & 100 & 0 & 0 & \\
\hline \multicolumn{6}{|l|}{ Cerebral event } \\
\hline No & 34 & 35.8 & 61 & 64.2 & ns \\
\hline Yes & 0 & 0 & 1 & 100 & \\
\hline \multicolumn{6}{|l|}{ Main coronary lesion } \\
\hline No & 31 & 34.8 & 58 & 65.2 & $0.48^{b}$ \\
\hline Yes & 3 & 42.9 & 4 & 57.1 & \\
\hline \multicolumn{6}{|l|}{ IABP } \\
\hline No & 33 & 36.3 & 58 & 63.7 & ns \\
\hline Yes & 1 & 20.0 & 4 & 80 & \\
\hline
\end{tabular}

aMann-Whitney U Test; bYate's Correction Test or Fischer's Exact Test; $\mathrm{p}<0.05$ is accepted as significant. ECMO: Extracorporeal membrane oxygenation; LITA: Left Internal Thoracic Artery; RITA: Right Internal Thoracic Artery; IABP: Intraaortic Balloon Pump; EF: Ejection fraction); SD: Standard deviation; ns: non-statistical. 


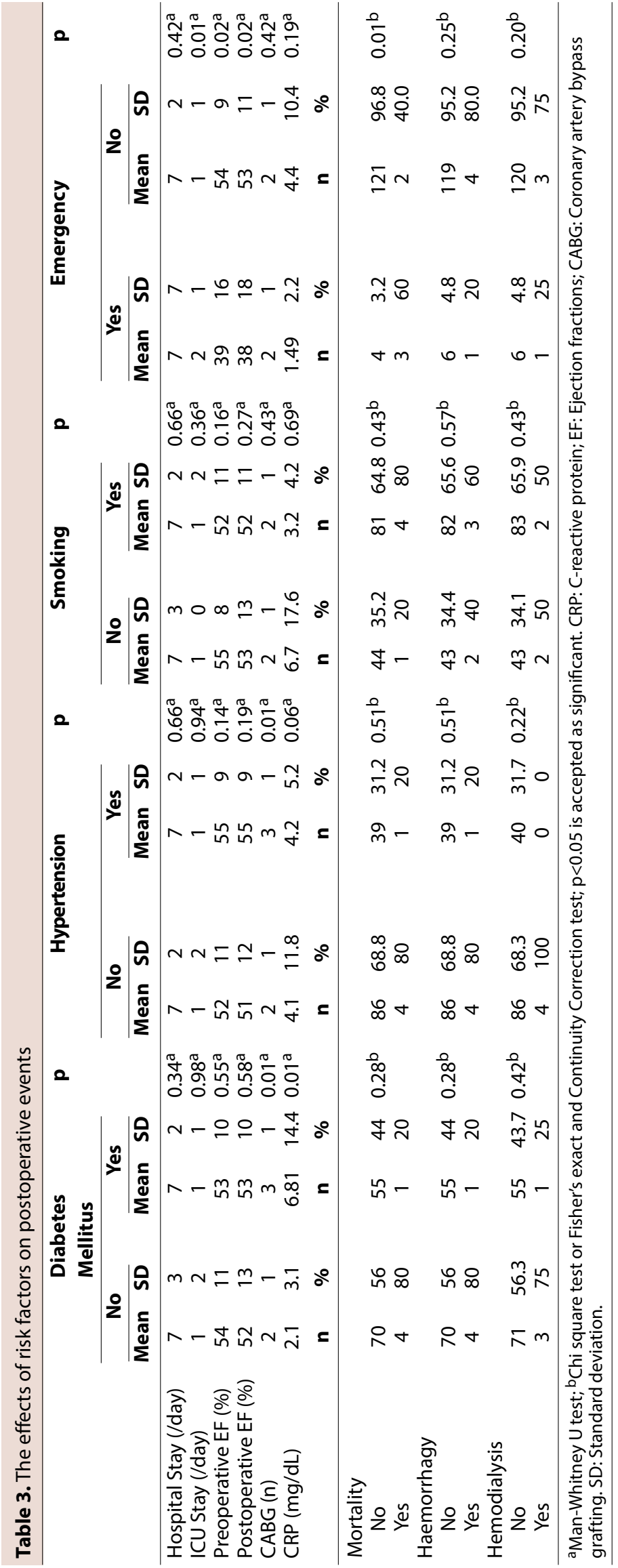

Table 4. Distribution of postoperative findings of cases by gender

\begin{tabular}{|c|c|c|c|c|c|}
\hline & \multicolumn{2}{|c|}{$\begin{array}{c}\text { Female } \\
(n=12)\end{array}$} & \multicolumn{2}{|c|}{$\begin{array}{c}\text { Male } \\
(n=118)\end{array}$} & \multirow[t]{2}{*}{$\mathbf{p}$} \\
\hline & Mean & SD & Mean & SD & \\
\hline Hospitalization (days) & 8 & 4 & 7 & 2 & $0.53^{a}$ \\
\hline Intensive care (days) & 1 & 1 & 1 & 1 & $0.76^{\mathrm{a}}$ \\
\hline Postoperative EF (\%) & 55 & 9 & 52 & 12 & $0.63^{a}$ \\
\hline Number of Coronary & 2 & 1 & 2 & 1 & $0.37^{a}$ \\
\hline \multicolumn{6}{|l|}{ Bypasses } \\
\hline & $\mathbf{n}$ & $\%$ & $\mathbf{n}$ & $\%$ & $\mathbf{p}$ \\
\hline \multicolumn{6}{|l|}{ Mortality } \\
\hline No & 12 & 9.6 & 113 & 90.4 & $1.00^{\mathrm{b}}$ \\
\hline Yes & 0 & 0 & 5 & 100 & \\
\hline \multicolumn{6}{|l|}{ Bleeding Revision } \\
\hline No & 12 & 9.6 & 113 & 90.4 & $1.00^{\mathrm{b}}$ \\
\hline Yes & 0 & 0 & 5 & 100 & \\
\hline \multicolumn{6}{|l|}{ The need for dialysis } \\
\hline No & 11 & 8.7 & 115 & 91.3 & $0.32^{b}$ \\
\hline Yes & 1 & 25 & 3 & 75 & \\
\hline \multicolumn{6}{|l|}{ LIMA usage } \\
\hline No & 1 & 14.3 & 6 & 85.7 & $0.50^{b}$ \\
\hline Yes & 11 & 8.9 & 112 & 91.1 & \\
\hline \multicolumn{6}{|l|}{ RIMA usage } \\
\hline No & 12 & 9.5 & 114 & 90.5 & $1.00^{b}$ \\
\hline Yes & 0 & 0 & 4 & 100 & \\
\hline \multicolumn{6}{|c|}{ OPCAB on Beating Heart } \\
\hline No & 11 & 9.3 & 107 & 90.7 & $1.00^{b}$ \\
\hline Yes & 1 & 8.3 & 11 & 91.7 & \\
\hline \multicolumn{6}{|l|}{ Postoperative stroke } \\
\hline No & 12 & 9.4 & 116 & 90.6 & $1.00^{b}$ \\
\hline Yes & 0 & 0 & 2 & 100 & \\
\hline
\end{tabular}

aMann-Whitney U Test; 'b Yate's Correction Test or Fischer's Exact Test; $\mathrm{p}<0.05$ is accepted as significant. LITA: Left Internal Thoracic Artery; RITA: Right Internal Thoracic Artery; OPCAB: Off-Pump Coronary Artery Bypass; Sd: Standard devaition.

stay was $1.28 \pm 1.3$ days. Four patients (3.08\%) developed atrial fibrillation, while 10 patients (7.6\%) experienced ventricular extrasystole requiring medical intervention. One patient $(0.7 \%)$ had a prolonged entubation period as a result of acute respiratory distress syndrome (ARDS). The 30-day mortality rate was $3.85 \%$ (5 patients). Among the patients undergone an emergent operation, three patients had early mortality. These patients had been taken into operation with CPR instituted in the catheter laboratory as a result of cardiac arrest following unsuccessful primary $\mathrm{PCI}$. Among the electively operated patients, only two patients had early mortality. One of these two patients had been suffering from Behcet's Disease. After multiple postoperative explorations for bleeding thought to be originating from vascular fragility intrinsic to Behcet's Disease, the patient developed bleeding diathesis. Following bleeding diathesis, in ICU follow-up, the patient died as a result of multiple 
organ failure on a postoperative day 15 . The other patient developed ARDS. Pulmonary infection and an acute renal failure further added to the clinical picture leading the patient to death on the postoperative $28^{\text {th }}$ day. The patients without any significant problems during their hospital stay were discharged on the average postoperative 7.1 \pm 1.5 day.

\section{Postoperative Follow-up}

Patient follow-up was accomplished by control examinations carried out in the first week, the first month and the second month in cardiovascular surgery clinique after hospital discharge, and in cardiology clinic thereafter. Moreover, phone calls, national patient database, and death notification database were other means of obtaining information related to patients in follow-up. Mean follow-up time per patient was $80.6 \pm 19.3$ months. Thirty-two patients (27.82\%) were found to continue smoking during follow-up. Twenty patients (17.39\%) developed psychological changes, such as nervousness, aggressiveness and fear of death.

The findings showed that 36 patients (31.30\%) applied to the hospital with cardiac complaints, such as angina pectoris, dyspnea, and exercise intolerance over the course of follow-up. Accordingly, the cardiac event-free survival rate was $68.70 \%$. In 24 patients out of 36 patients with cardiac complaints, effort test and myocardial perfusion scintigraphy (MPS) revealed no pathological finding. Thus, the existing medical treatment they had been receiving was continued. Totally, 12 patients [two patients in postoperative 48 months, four patients in postoperative 72 months, and six patients in postoperative 96 months] underwent coronary angiography due to ischemic findings in MPS. In 10 patients (91\%), LITA-LAD anastomosis was patent, and 17 out of 22 saphenous grafts $(79 \%)$ used in 12 patients were found to be patent. Two patients with LITA-LAD and saphenous vein graft (SVG) occlusions underwent CABG surgery, one patient with new RITA-LAD, Ao-SVG-CxOM1, Ao-SVG-RCA anastomoses in postoperative month 48 , and the other one patient with new Ao-SVG-LAD, and Ao-SVGCx anastomoses in postoperative month 72. Cardiac and/or noncardiac mortality in patients aged between 17 and 35 who underwent CABG was detected to be $9 \%(n=10)$.

Survival rates at postoperative $12^{\text {th }}$ month, $72^{\text {nd }}$ month, and $96^{\text {th }}$ month calculated by Kaplan-Meier test were found to be $99.2 \%, 97.4 \%$, and $83.1 \%$, respectively (Fig. 1). Average life expectancy was found to be $97 \pm 1 \%(95 \%$ $\mathrm{Cl}=95-99)$. Effect of the diabetes mellitus on average life expectancy was found to be significant. [Survival rate at the

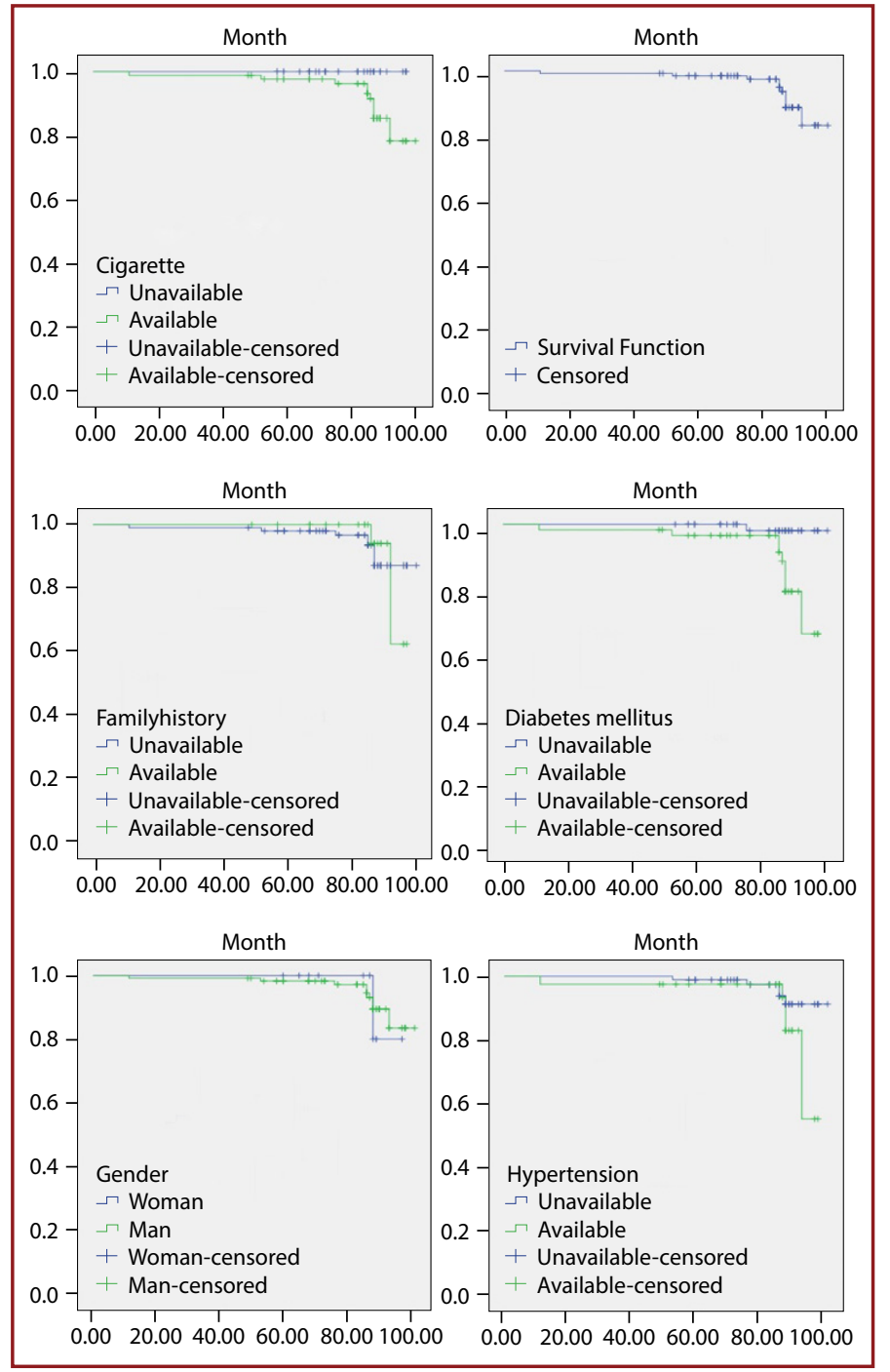

Figure 1. In the Kaplan-Meier Log Rank Analysis, the cumulative life expectancy analysis showed diabetes mellitus, hypertension, family history, smoking, and gender distribution.

postoperative 96th month was $92.2 \%$ (95\% Cl=88.7-95.7) in patients with diabetes mellitus, while it was $99.5 \%$ (95\% $\mathrm{Cl}=98.6-100.5)$ in patients without diabetes mellitus. Kaplan Meier Log Rank $p=0.005]$. Likewise, the survival rate at the postoperative 96th month was $91.9 \%(95 \% \mathrm{Cl}=87.2$ 96.8) in patients with arterial hypertension, whereas it was 98.2\% (95\% Cl=96,7-99.8) in patients without arterial hypertension (Kaplan Meier Log Rank $\mathrm{p}=0.18$; mean \%98.2; 95\% $\mathrm{Cl}=96.6-99.8)$. Moreover, the difference in cumulative life expectancy between patients with smoking history and without smoking history was found to be statistically considerable. Survival rate at the postoperative 96th month was $88.4 \%(95 \% \mathrm{Cl}=86.4-90.8)$ in patients with smoking history, while it was $99.8 \%(95 \% \mathrm{Cl}=97.3-100.6)$ in patients without smoking history (Kaplan Meier Log Rank $p=0.067$ ). 
On the other hand, the presence of positive family history on the survival rate at the postoperative 96th month was detected to be statistically insignificant. (Kaplan Meier Log Rank $p=0.897$ ). The survival rate at the postoperative 96th month was $97.2 \%$ for the patients with a positive family history ( $95 \% \mathrm{Cl}=95-99)$, while it was $94.8 \%$ for the patients with a negative family history ( $\mathrm{p}=0.897 ; 95 \% \mathrm{Cl}=92-97)$. As for the effects of gender difference on the survival rate, no statistically significant difference was found (Kaplan Meier Log-rank $p=0.883$ ). Survival rates at the postoperative 96 th month were $94.2 \%$ for females $(95 \% \mathrm{Cl}=91-97)$ and $97.0 \%$ for males $(\mathrm{p}=0.883 ; 95 \% \mathrm{Cl}=94-99)$.

\section{Discussion}

The incidence of coronary artery disease in young adults has been increasing even though it is primarily the disease of the middle and advanced aged population. Increased prevalence of conventional risk factors in coronary artery diseases, such as smoking, alcohol addiction, hypertension, hyperlipidemia, diabetes mellitus, sedentary lifestyle, obesity, and family history, are reported to play a role in this trend ${ }^{[6,7]}$. Cohen et al. ${ }^{[8]}$ reported that smoking, hypertension, diabetes mellitus, and family history are the major risk factors contributing to increased CABG rates in the young population. Rival et al. ${ }^{[9]}$ noted that smoking lowers the threshold for myocardial ischemia by reducing the oxygen-carrying capacity of the blood. It has also been reported that smoking elevates fibrinogen levels and provokes platelet aggregation. Frei et al. [10] stated that smoking nullifies cardioprotective effects of HDL through direct endothelial injury brought about by carbon monoxide and nicotine. Particularly smoking is the leading cause of early-onset ischemic heart disease. As it is reported in the Interheart Study conducted in $>50$ countries, the cardiac risk is higher in smokers aged 40 and below than in elders ${ }^{[11]}$. Aygul et al. ${ }^{[12]}$ reported that smoking is the most important risk factor for coronary artery disease in Turkish society. In our study, smoking prevalence, particularly in male, determined to be significantly high $(p=0.023)$. Smoking history, above all, prolongs the length of hospitalization in patients undergone CABG. Moreover, it is found that smoking is a key player in life expectancy during the postoperative follow-up of patients undergone CABG. Since it has been found that smoking in the postoperative period continued to a large extent, smoking could be the most important modifiable cardiovascular risk factor.
Diabetes mellitus is an independent risk factor for coronary artery disease ${ }^{[13]}$. Magnus et al. ${ }^{[14]}$ reported that diabetes mellitus is an important cardiovascular risk factor in the young population. Among young patients undergone CABG we studied, nearly one-third of females and more than half the males being diagnosed with diabetes mellitus indicate that diabetes mellitus is an important cardiovascular risk factor in the young population. In our study, it had strikingly been detected that the number of bypassed vessels was higher in young diabetic patients, and diabetes mellitus had a significant effect on the life expectancy of patients undergone $C A B G$.

The discrepancy between the male and female concerning coronary artery prevalence is attributable to the proatherogenic properties of testosterone versus antiatherogenic properties of endogen estrogen ${ }^{[15]}$. Although female patients are advantageous concerning coronary artery disease at early ages, after menopause, the risk comes up to similar levels with males ${ }^{[16]}$.

CRP levels have an impact on the long term risk stratification and prognosis of coronary artery disease ${ }^{[17]}$. Haverkate et al. ${ }^{[18]}$ reported that CRP levels $>3.6 \mathrm{mg} / \mathrm{dL}$ double the risk of a coronary event. Yamashita et al. ${ }^{[19]}$ found CRP levels to be higher in individuals with stable and/or unstable angina pectoris compared to healthy individuals. Rettersol et al. [20] suggested that CRP is an indicator of cardiovascular events and death in those experienced myocardial infarctions at early ages. In our study, $47.69 \%$ of the patients had higher than normal CRP levels in addition to higher $\mathrm{fT}_{3}(p=0.008)$ and HDL $(p=0.039)$ levels, which support the relationship between coronary artery disease and high CRP levels.

Behcet's Disease is a chronic inflammatory disease with oral aphthae, genital ulcers, and ocular lesions. In 5\% of patients suffering from Behcet's Disease, aortic and mitral valve regurgitation, and endomyocardial fibrosis could be seen ${ }^{[21]}$. Coronary artery disease uncommonly accompanies Behcet's Disease and primarily affects the young population. Even though in its remission period, Behcet's Disease may bring along some serious postoperative complications in the case of cardiac surgery. In Behcet's Disease, vascular fragility is the most important challenging factor for surgical interventions. In literature, reports on CABG and Behcet's Disease are in the minority ${ }^{[22]}$. Within our patient population, one young male has been operated electively while he was under steroid treatment. In the immediate postoperative period, the patient underwent multiple surgical revisions due to bleeding complications attributed 
to vascular fragility intrinsic to Behcet's Disease. The patient died as a result of bleeding diathesis. We recommend that patients with Behcet's Disease, one of the rarely encountered diseases, must be taken into CABG surgery while the disease is in its remission period, and that target vessel and the number of grafts planned to be used should be precisely evaluated.

In the coronary artery bypass surgery, there is no difference between the young and older patients concerning surgical approach and method. The young patients have faster convalescence and earlier recovery to normal life than older patients ${ }^{[23,24]}$. This was also confirmed in our study.

\section{Restricting Factors}

In a similar way, the published literature on young patients underwent $C A B G$. Our study falls short of the number of patients that needed for the formation of a strong opinion though the young represent a small proportion of the total population $(0.62 \%)$ of patients undergone CABG in our center. Therefore, multicenter studies on this subject may be more valuable. Moreover, genetic evaluation of cases, autoantibody studies, and getting coronary artery biopsies were impossible since the study was conducted retrospectively. We consider that newly designed studies that will compare far-reaching data derived from the young cases to data derived from older cases would help get favorable results.

\section{Conclusion}

In conclusion, when analyzed deeply, family history, smoking and diabetes mellitus in young patients underwent CABG are statistically significant risk factors, latter two being preventable and manageable. These three risk factors also play a profound role in life expectancy, too. CABG surgery could be carried out with low mortality and perioperative complication rates in young adults, thus could contribute to the length and quality of their lives. The avoidance of coronary artery risk factors postoperatively could ensure coronary event-free decades.

Ethics Committee Approval: The Ethics Committee of Dr. Siyami Ersek Training and Research Hospital provided the ethics committee approval for this study (11.02.2015-28001928-501.07.01).

Peer-review: Externally peer-reviewed.

Authorship Contributions: Concept: M.K.; Design: M.K., Ü.V.; Data Collection or Processing: M.K., Z.A.; Analysis or Interpretation: Ü.V., A.A.A.; Literature Search: A.Y.B., A.A.A.; Writing: M.K.
Conflict of Interest: None declared.

Financial Disclosure: The authors declared that this study received no financial support.

\section{References}

1. Hennekens $\mathrm{CH}$. Increasing burden of cardiovascular disease: current knowledge and future directions for research on risk factors. Circulation 1998;97:1095-102. [CrossRef]

2. Klein LW, Nathan S. Coronary artery disease in young adults. J Am Coll Cardiol 2003 19;41:529-31. [CrossRef]

3. McGill HC Jr, McMahan CA, Zieske AW, Tracy RE, Malcom GT, Herderick EE, et al. Association of coronary heart disease risk factors with microscopic qualities of coronary atherosclerosis in youth. Circulation 2000;102:374-9. [CrossRef]

4. Kelly ME, DeLaria GA, Najafi H. Coronary artery bypass surgery in patients less than 40 years of age. Chest 1988;94:1138-41.

5. Lytle BW, Kramer JR, Golding LR, Cosgrove DM, Borsh JA, Goormastic $M$, et.al. Young adults with coronary atherosclerosis; 10 year results of surgical myocardial revascularization. J Am Coll Cardiol 1984;4:445-53. [CrossRef]

6. Khot UN, Khot MB, Bajzer CT, Sapp SK, Ohman EM, Brener SJ, et al. Prevalance of conventional risk factors in patients with coronary heart disease. JAMA 2003;290:898-904. [CrossRef]

7. Hoit BD, Gilpin EA, Henning H, Maisel AA, Dittrich $H$, Carlisle J, et al. Myocardial infarction in young patients; an analysis by age subsets. Circulation 1986;74:712-21. [CrossRef]

8. Cohen DJ, Basamania C, Graeber GM, Deshong JL, Burge JR. Coronary artery bypass grafting in young patients under 36 years of age. Chest 1986;89:811-6. [CrossRef]

9. Rival J, Riddle JM, Stein PD. Effects of chronic smoking on platelet function. Thromb Res 1987;45:75-85. [CrossRef]

10. Frei B, Forte TM, Ames BN, Cross CE. Gas phase oxidants of cigarette smoke induce lipid peroxidation and changes in lipoprotein properties in human blood plasma: Protective effects of ascorbic acid. Biochem J 1991;277:133-8. [CrossRef]

11. Teo KK, Ounpuu S, Hawken S, Pandey MR, Valentin V, Hunt D, et al. Tobacco use and risk of myocardial infarction in 52 countries in the INTERHEART study: a case-control study. Lancet 2006;368:647-58. [CrossRef]

12. Aygul N, Ozdemir K, Abaci A, Aygul MU, Duzenli MA, Yazici $\mathrm{HU}$, et al. Comparison of traditional risk factors, angiographic findings, and in-hospital mortality between smoking and nonsmoking Turkish men and women with acute myocardial infarction. Clin Cardiol 2010;33:E49-54. [CrossRef]

13. Grundy SM, Benjamin IJ, Burke GL, Chait A, Eckel RH, Howard $B V$, et al. Diabetes and cardiovascular disease: A statement for healthcare professionals from the American Heart Association. Circulation 1999;100:1134-46. [CrossRef]

14. Dalén $M$, Ivert T, Holzmann MJ, Sartipy U. Coronary artery bypass grafting in patients 50 years or younger: a Swedish nationwide cohort study. Circulation 2015;131:1748-54. [CrossRef]

15. Christian RC, Harrington S, Edwards WD, Oberg AL, Fitzpatrick LA. Estrogen status correlates with the calcium content of coronary atherosclerotic plaques in women. J Clin Endocrinol 
Metab 2002;87:1062-7. [CrossRef]

16. Ablewska U, Jankowski K, Rzewuska E, Liszewska-Pfejfer D, Hryniewiecki T. A levels of endogenous gonadal hormones and their relationship with selected coronary artery disease risk factors among young women post myocardial infarction. Acta Biochim Pol 2011;58:385-9. [CrossRef]

17. Perry TE, Muehlschlegel JD, Liu KY, Fox AA, Collard CD, Body $\mathrm{SC}$, et al. Preoperative C-reactive protein predicts long-term mortality and hospital length of stay after primary, nonemergent coronary artery bypass grafting. Anesthesiology 2010;112:607-13. [CrossRef]

18. Haverkate F, Thompson SG, Pyke SD, Gallimore JR, Pepys MB. Production of $\mathrm{C}$-reactive protein and risk for coronary events in stable and unstable angina. European Concerted Action on Thrombosis and Disabilities Angina Pectoris Study Group. Lancet 1997;349:462-6. [CrossRef]

19. Yamashita H, Shimada K, Seki E, Mokuno H, Daida H. Concentrations of interleukins, interferon, and C-reactive pro- tein in stable and unstable angina pectoris. Am J Cardiol 2003;91:133-6. [CrossRef]

20. Retterstol L, Eikvar L, Bohn M, Bakken A, Erikssen J, Berg K. C-reactive protein predicts death in patients with previous premature myocardial infarction a 10 year follow up study. Atherosclerosis 2002;160:433-40. [CrossRef]

21. Akar H, Konuralp C, Akpolat T. Cardiovascular involvement in Behcet's Disease. Anadolu Kardiyol Derg 2003;3:261-5.

22. Sismanoglu M, Omeroglu SN, Mansuroglu D, Ardal H, Erentug V, Kaya $E$, et al. Coronary artery disease and coronary artery bypass grafting in Behçet's disease. J Card Surg 2005;20:1603. [CrossRef]

23. Gelfand ET, Wartak J, Callaghan JC. Coronary artery bypass in patients under 40 years of age. Can J Surg 1983;26:188-9.

24. Zwoliński R, Jander S, Ostrowski S, Bartczak K, Adamek Kośmider A, Banyś A, et al. Early and long term coronary artery bypass grafting outcomes in patients under 45 years of age. Kardiol Pol 2013;71:32-9. 